\title{
Unilateral dudak damak yarığına sahip hastalarda farengeal havayolunun değerlendirilmesi ${ }^{\star}$
}

\author{
Zeliha Müge Baka ${ }^{\alpha}$, Emire Aybüke Erdur ${ }^{\beta}$, Sevtap Alp ${ }^{\alpha}$, Faruk Ayhan Başçiftçi ${ }^{\alpha}$
}

Selcuk Dent J, 2017; 4: 170-177 (Doi: 10.15311/selcukdentj.336658)

Başvuru Tarihi: 01 Eylül 2017 Yayına Kabul Tarihi: 11 Kasım 2017

\section{öz}

Unilateral dudak damak yarığına sahip hastalarda farengeal havayolunun değerlendirilmesi

Amaç: $\mathrm{Bu}$ çalışmanın amacı unilateral tam dudak damak yarığına (UDDY) sahip hastaların farengeal hava yolu alanı, yumuşak damak ölçümleri ve kraniyoservikal postürünün değerlendirilmesi ve bu değerlerin dudak damak yarığına sahip olmayan kontrol grubu hastaları ile karşılaştırılmasıdır.

Gereç ve Yöntemler: Çalışmaya rastgele ve retrospektif olarak seçilen 60 hasta dahil edilmiştir ve 2 gruba ayrılmıştır. Birinci grup UDDY (30 hasta; ortalama yaş, 15,07 $\pm 5,61$ yıl), ikinci grup ise DDY olmayan iskeletsel Sınıf I (30 hasta; ortalama yaş, $16,34 \pm 3,18$ yıl) hastalardan oluşmaktadır. Hastalardan alınan lateral sefalometrik filmler üzerinde farengeal hava yolu alanları, yumuşak damak ölçümleri ve kraniyoservikal postür açıları hesaplanmıştır. Elde edilen verilerin gruplar arası karşılaştırmasında bağımsız T-testi kullanılmıştır.

Bulgular: UDDY grubundaki hastaların kontrol grubuna kıyasla önemli ölçüde daha küçük toplam ve aerial nazofarengeal alana sahip olduğu bulunmuştur $(P<0,05)$. Ayrıca UDDY grubundaki hastaların yumuşak damaklarının daha kalın ve daha kısa olduğu bulunmuştur $(P<0,05)$. Adenoidal nazofarengeal alan, orofarengeal alan, sert damak/yumuşak damak açıSı (ANS-PNS- $\mathrm{P}^{\circ}$ ) ve kranioservikal postür açılarında (NSL/CVT ${ }^{\circ}$ ve $\mathrm{NSL}^{-O P T^{\circ}}$ ) iki grup arasında istatistiksel olarak anlamlı bir farklılık bulunmamışıı $(P>0,05)$.

Sonuç: UDDY sahip hastaların toplam ve aerial nazofarengeal alanları kontrol grubuna göre daha küçüktür. Bu nedenle bu hastalarda tedavi planlaması yapılırken farengeal hava yolu üzerine pozitif bir etkiye sahip olmasına dikkat edilmelidir.

\section{ANAHTAR KELIMELER}

Havayolu, sefalometri, yarık damak, yarık dudak

Dudak damak yarıkları, kraniyofasiyal bölgenin en sık rastlanan konjenital anomalisidir ve patogenezinde genetik ve çevresel faktörlerin etkili olduğu belirtilmektedir. ${ }^{1,2} \mathrm{Bu}$ anomali tek başına gözlenebileceği gibi diğer kraniyofasiyal anomalilere

\section{ABSTRACT}

Evaluation of pharyngeal airway in patients with unilateral cleft lip palate

Background: The aim of this study was to evaluate the pharyngeal airway area, soft palate measurements and craniocervical posture of patients with unilateral cleft lip palate (UCLP) and compare these with control group patients who do not have a cleft.

Methods: Sixty patients randomly and retrospectively selected were included in the study and divided into 2 groups. The first group consisted of UCLP patients (30 patients, mean age, 15.07 \pm 5.61 years) and the second group consisted of skeletal Class I patients with no cleft ( 30 patients, mean age, $16.34 \pm 3.18$ years). The pharyngeal airway areas, soft palate measurements and craniocervical posture angles were calculated on the lateral cephalometric films taken from the patients. Independent T-test was used to compare the data between groups.

Results: Patients in the UCLP group were found to have significantly smaller total and aerial nasopharyngeal area than the control group $(P<0,05)$. In addition, the patients in the UCLP group were found to have thicker and shorter soft palates $(P$ $<0.05)$. There was no statistically significant difference between the two groups in adenoidal nasopharyngeal area, oropharyngeal area, hard palate/soft palate angle (ANS-PNS- ${ }^{\circ}$ ) and craniocervical posture angle (NSL/CVT' ${ }^{\circ}$ and NSL-OPT $\left.{ }^{\circ}\right)(P>0,05)$.

Conclusion: The total and the aerial nasopharyngeal areas of patients with UCLP are smaller than the control group. Therefore, care should be taken to ensure that there is a positive effect on the pharyngeal airway when treatment planning is performed in these patients.

\section{KEYWORDS}

Airway, cephalometry, cleft palate, cleft lip

de eşlik edebilmektedir. Farengeal boyutlar ve kraniyofasiyal anomaliler arasındaki belirgin ilişki nedeniyle, kraniyofasiyal modelin hava yoluna ait yapıları etkilemesi beklenmektedir. ${ }^{3,4}$

\footnotetext{
* Bu çalışma Dudak Damak Yarıkları Derneği 3. Uluslararası Kongresi (1-4 Aralık 2016, Konya, Türkiye)'nde “Unilateral Dudak Damak Yarı̆̆ına Sahip Hastalarda Faringeal Havayolunun Değerlendirilmesi” başlğ̆ıla sözlü bildiri olarak sunulmuştur.

Bu çalışmada herhangi bir çıkar/ilişki çatışması yoktur.

${ }^{\alpha}$ Selçuk Üniversitesi Diş Hekimliği Fakültesi Ortodonti Anabilim Dalı, Konya

${ }^{\beta}$ Necmettin Erbakan Üniversitesi Diş Hekimliği Fakültesi Ortodonti Anabilim Dalı, Konya
} 
Dudak damak yarıklı bireylerin kraniyofasiyal morfolojisi, yarık olmayan bireylerden farklıdır. ${ }^{5,6} \mathrm{Bu}$ bireylerde maksillanın veya mandibulanın retrognatik olması, maksiller darlık, kısa mandibular gövde, mandibulanın geri ve aşağı doğru rotasyonu ve buna bağlı artmış vertikal yükseklik de dahil olmak üzere farengeal havayolunun azalmasına yol açabilecek çeşitli kraniyofasiyal anomaliler gözlenebilmektedir. ${ }^{3-6}$ Bunlara; septal deviasyon, koanal atrezi, konka hipertrofisi, vomer deviasyonu ve alar darlık gibi burun anomalileri de eşlik edebilmektedir. ${ }^{7-9} \mathrm{Bu}$ anomaliler, hastalarda genellikle farengeal hava yolu azalmasına bağlı olarak; uyku esnasında ağız solunumu, horlama veya solunum güçlüğü şikayetlerini beraberinde getirmektedir. ${ }^{10}$ Dudak damak yarıklı hastalarda, maksiller ve mandibular yapısal anomaliler ile birlikte yumuşak damağı kontrol eden palatal kasların fonksiyon bozukluğu sonucu farengeal havayolunun azalması uykuda solunum bozukluğu açısından yüksek risk oluşturmaktadır. ${ }^{11}$ Uykuda solunum bozukluğu olan hastalarda hipertansiyon, kardiyovasküler ve serebrovasküler hastalıklar ve gün içerisinde aşırı uykulu olma riski artmaktadır. ${ }^{12}$ Dudak damak yarıklı hastalarda, eşlik eden anomaliler göz önünde bulundurulduğunda farengeal hava yolunun morfometrik değerlendirmesi önemlidir.

Havayolu, nazal direnç ve hava akımı testleri, nazoendoskopi, lateral sefalometri, manyetik rezonans görüntüleme (MRG), üç boyutlu (3D) görüntüleme (CT ve CBCT) gibi teşhis yöntemleri kullanılarak değerlendirilmiştir. Ancak, üst havayolunun obstrüksüyonunun teşhisinde bunlardan hangisinin altın standard olduğu konusunda bir uzlaşı yoktur. Son zamanlarda yapılan çalışmalar üç boyutlu görüntülemenin özellikle CBCT'nin altın standard olabileceğini işaret etse de CBCT konvansiyonel lateral sefalometriye göre daha masrafıdır ve radyasyon dozu daha yüksektir. Bu nedenle, ortodonti hastalarında CBCT'nin belirli amaçlar için sınırlanması önerilmektedir. Lateral sefalometrik radyografi üst havayolunun değerlendirilmesi için basit ve tekrarlanabilir bir yöntemdir. ${ }^{13}$ Önceki çalışmalar, farengeal hava yolu anomalilerinin teşhisinde güvenilir olduğunu ve sefalometrik görüntüdeki nazofarengeal havayolu boşluğu ile CBCT taramasındaki gerçek hacimsel boşluk arasında pozitif bir korelasyon olduğunu göstermiştir. ${ }^{14}$

Bu çalışmanın amacı, unilateral tam dudak damak yarığına sahip hastaların farengeal hava yolu alanı, yumuşak damak ölçümleri ve kraniyoservikal postürünün değerlendirilmesi ve bu değerlerin dudak damak yarığına sahip olmayan kontrol grubu hastaları ile karşılaşıııımasıdır. Bu çalışmanın sıfır hipotezi unilateral tam dudak damak yarığına sahip hastalar ile dudak damak yarı̆ıına sahip olmayan hastalar arasında farengeal hava yolu açısından herhangi bir fark yoktur şeklindedir.

\section{GEREÇ VE YÖNTEM}

Bu retrospektif çalışma Selçuk Üniversitesi Diş Hekimliği Fakültesi Ortodonti Anabilim Dalına ortodontik tedavi için başvurmuş hastaların tedavi öncesi arşiv kayıtları kullanılarak yürütülmüştür. Hastalar ve ebeveynleri, verilerinin bilimsel amaçlarla kullanılabilmesi için bilgilendirilmiş onam formu imzalamışlardır. Çalışmamızda örnek sayısının belirlenmesi için Gohilot ve ark. ${ }^{15}$ çalışmasındaki nazofarengeal alan ortalama ve standart sapma değerleri (UDDY: $801.87 \pm 284.44$; Kontrol: $1161.04 \pm$ 175.57) baz alınmış ve örnek sayısı 17'şer hasta olduğunda \%95 güce sahip olduğu tespit edilmiştir. Çalışma grubu için, üç yaşından önce aynı cerrahi prosedürle opere edilmiş, unilateral tam dudak damak yarığına (UDDY) sahip, rastgele 30 hasta (17 erkek, 13 kız; ortalama yaş, $15,07 \pm 5,61$ yıl) seçilmiştir. Kontrol grubu için ise aynı arşiv kayıtlarından, çalışma grubu ile yaşa ve cinsiyete göre eşleştirilmiş, dudak damak yarığı olmayan, normal büyüme paternine ve iskeletsel Sınıf I malokluzyona sahip 30 hasta (16 erkek, 14 kız; ortalama yaş, 16,34 $\pm 3,18$ yıl) seçilmiştir. Tonsillektomi, adeneidektomi ve tekrarlayan bademcik iltihabı hikayesi olan, sık soğuk algınlığı (yılda 6 veya daha fazla) geçiren, daha önce herhangi bir ortodontik tedavi gören, travma hikayesi olan ve herhangi bir sendromu bulunan hastalar çalışmaya dahil edilmemiştir. Tablo 1'de grupların SNA, SNB, ANB ve SNGoGn ortalama, standart sapma ve karşıllaştırmaları verilmiştir.

\section{Tablo 1.}

Grupların SNA, SNB, ANB ve SN-GoGn ortalama, standart sapma ve karşılaştırmaları

\begin{tabular}{|llccc|} 
Parametreler & Gruplar & Ortalama & SS & P \\
\hline \multirow{2}{*}{ SNA } & UDDY & 76,7 & 4,2 & \\
& Kontrol & 81,5 & 3,1 & 0.082 \\
\hline \multirow{2}{*}{ SNB } & UDDY & 76,6 & 3,7 & \\
& Kontrol & 79,4 & 2,9 & 0.344 \\
\hline \multirow{2}{*}{ ANB } & UDDY & 0,1 & 3,6 & \\
& Kontrol & 2,1 & 1,1 & 0.000 \\
\hline \multirow{2}{*}{ SN-GoGn } & UDDY & 36,3 & 6,6 & \\
& Kontrol & 35.0 & 4,7 & 0.421 \\
\hline
\end{tabular}

SS: standart sapma 
Hastaların farengeal hava yolu alanları, yumuşak damak ölçümleri ve kraniyoservikal postür açıları lateral sefalometrik filmler ile değerlendirilmiştir. Lateral sefalometrik filmler, aynı röntgen cihazı (Planmeca ProMax, Helsinki, Finlandiya) kullanılarak, Frankfurt horizontal düzlemi yere paralel olacak şekilde, dişler sentrik okluzyonda iken alınmıştır. Tüm filmler aynı bilgisayarda, aynı araştırmacı (SA) tarafından, Adobe Reader XI (sürüm 11.0.22 Adobe Systems, Kaliforniya, ABD) yazılımı kullanılarak kör olarak analiz edilmiştir. Şekil 1 ve Şekil 2 sırasıyla toplam, adenoidal, aerial nazofarengeal ve orofarengeal alanlar ile yumuşak damak ve kranioservikal açı ölçümlerinin analizinde kullanılan referans nokta ve düzlemleri göstermektedir. Şekil 1'de gösterildiği gibi palatal düzlem (ANS-PNS), Basion (Ba) noktasından sfenoid kemiğin alt kenarına teğet geçen sfenoid düzlem ve bir tanesi atlasın ön noktasından (Aa) diğeri pterigomaksiller fissürden $(\mathrm{Pm})$ olmak üzere palatal düzleme dik iki çizgi referans olarak alınarak toplam nazofarengeal alan hesaplanmıştır. Toplam nazofarengeal alanı ifade eden yamuk içerisinde adenoidal ve aerial nazofarengeal alanlar belirlenmiştir. Orofarengeal havayolunun sınırları ise arkada posterior faringeal duvar, önde dil ve yumuşak damağın dorsal kısmı, üstte posterior faringeal duvara kadar uzanan palatal düzlem altta ise bu düzleme paralel ve epiglottisin tepesine teğet geçen düzlemdir. ${ }^{16}$ Şekil 2'de gösterildiği gibi yumuşak damak pozisyonunun sefalometrik değerlendirilmesinde yumuşak damağın en uç noktası referans olarak kullanılmıştır. Yumuşak damak uzunluğu posterior nazal spina (PNS) ile yumuşak damağın ucu (P) arasındaki mesafe olarak, yumuşak damak kalınlığı da yumuşak damak uzunluk hattına dik olarak ölçülen yumuşak damağın maksimum kalınlığı (SP1SP2) olarak ölçülmüştür. Yumuşak damak açısı da anterior nazal spina, posterior nazal spina ile yumuşak damağın ucu arasında kalan açı (ANS-PNS-P)'dır. Kranioservikal postürün değerlendirilmesinde kranioservikal açılar kullanılmıştır. Şekil 2'de gösterildiği gibi bu açılar da Sella (S) -Nasion (N) düzlemi ile 2. vertebranın üst (Cv2tg) ve alt (Cv2ip) arka sınırından geçen düzlem (OPT) ile 2. vertebranın üst arka (Cv2tg) ve 4. vertebranın alt arka (Cv4ip) sınırlarından geçen düzlem (CVT) arasında kalan açılardır. ${ }^{16}$

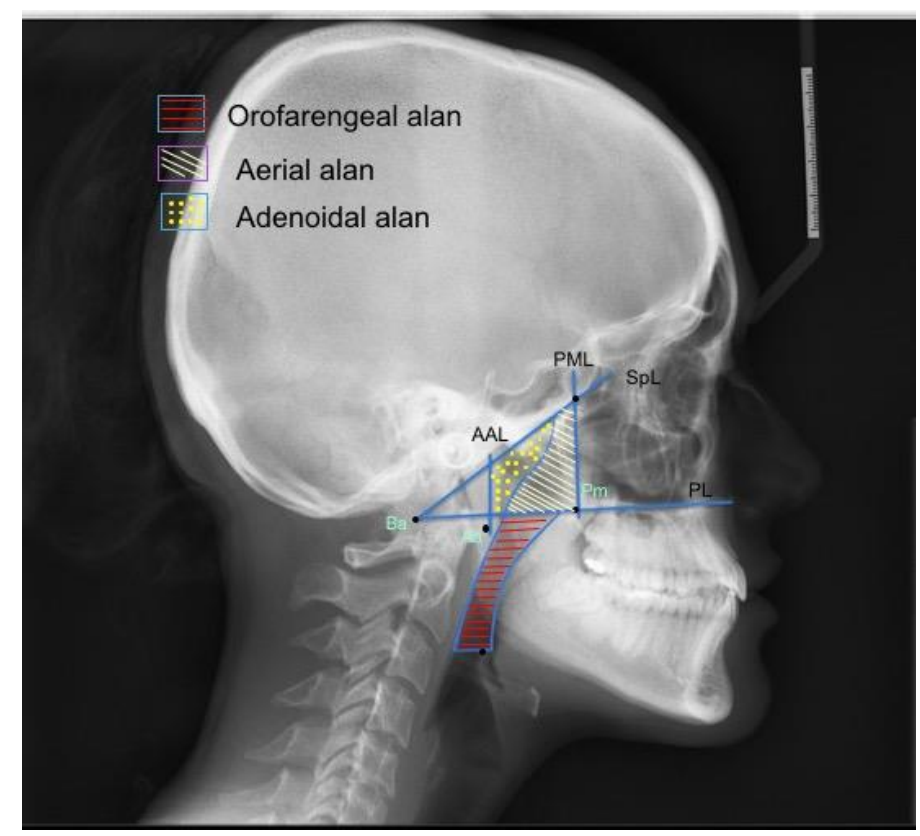

Şekil 1.

Nazofarengeal (Aerial+Adenoidal) ve orofarengeal alan

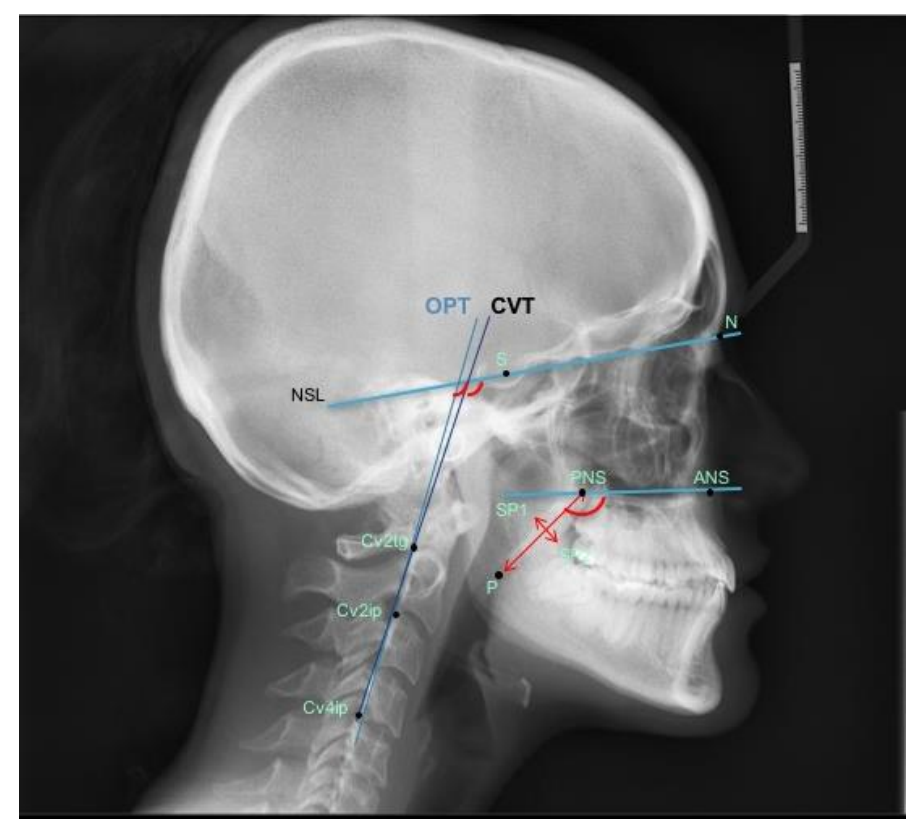

Şekil 2.

Kraniyoservikal postür açıları ve yumuşak damak ölçümleri 


\section{İstatistiksel analiz}

İstatistiksel analizler SPSS yazılımı (version 17.0, SPSS, Chicago, II) kullanılarak yapılmıştır. Verilerin normalitesini değerlendirmek için Shapiro-Wilks testi ve varyans homojenitesini değerlendirmek için Levene's testi uygulanmıştır. Elde edilen verilerin gruplar arası karşılaştırmasında bağımsı örneklem t-testi kullanılmıştır.

Metod hatasını belirlemek için, her iki gruptan rastgele seçilen 12 adet lateral sefalometrik filmin çizim ve ölçümleri aynı araştırmacı tarafından 2 hafta sonra tekrarlanmıştır. Ölçümlerin güvenilirliğini değerlendirmek için Houston ${ }^{17}$ tarafından tarif edilen sınıf içi korelasyon katsayıları hesaplanmış ve en düşük değerin $r=0,908$ olduğu bulunmuştur.

\section{BULGULAR}

Grupların havayolu alan değerlerinin ortalamaları ve standart sapmaları Tablo 2'de verilmiştir. Nazofarengeal havayolu alan değerleri UDDY grubunda kontrol grubuna göre daha düşük olmakla beraber, orofarengeal havayolu alan değerleri kontrol grubuna göre daha yüksektir. Gruplar arasında aerial alan ve total alan değerleri arasında istatistiksel olarak anlamlı farklar bulunmuştur. UDDY grubundaki hastaların kontrol grubuna kıyasla önemli ölçüde daha küçük toplam ve aerial nazofarengeal alana sahip olduğu bulunmuştur $(P \quad<0,05)$. Adenoidal alan ve orofarengeal alan gruplar arasında istatistiksel olarak anlamlı bir farklıık göstermemiştir.

\section{Tablo 2.}

Grupların havayolu alan değerlerinin ortalama, standart sapma ve karşılaştırmaları

\begin{tabular}{|lllccc|}
\hline Ölçümler & Gruplar & $\mathbf{N}$ & Ortalama & SS & P \\
\hline $\begin{array}{l}\text { Adenoidal } \\
\text { alan }\left(\mathbf{m m}^{2}\right)\end{array}$ & UDDY & 30 & 260,08 & 50,64 & 0.135 \\
\hline $\begin{array}{l}\text { Aerial alan } \\
\left.\text { Kmm }^{\mathbf{2}}\right)\end{array}$ & UDDY & 30 & 308,80 & 89,03 & 0.006 \\
\hline $\begin{array}{l}\text { Total alan } \\
\left.\text { (mm }^{\mathbf{2}}\right)\end{array}$ & UDDY & 30 & 568,89 & 103,17 & 0.002 \\
\hline $\begin{array}{l}\text { Orofarengeal } \\
\text { alan }\left(\mathbf{m m}^{\mathbf{2}}\right)\end{array}$ & Kontrol & 30 & 644,09 & 75,75 & \\
\hline
\end{tabular}

N: örnek sayısı; SS: standart sapma
Grupların yumuşak damak ölçüm değerlerinin ortalamaları ve standart sapmaları Tablo 3'de görülmektedir. Yumuşak damak açısı gruplar arasında istatistiksel olarak anlamlı bir farklılık göstermezken, yumuşak damak kalınlığı ve uzunluğu gruplar arasında istatistiksel olarak anlamlı farklılık göstermiştir $(P<0,05)$. UDDY grubundaki hastaların yumuşak damaklarının daha kalın ve daha kısa olduğu bulunmuştur $(P<0,05)$.

Tablo 3.

Grupların yumuşak damak ölçüm değerlerinin ortalama, standart sapma ve karşılaştırmaları

\begin{tabular}{|lllccc|}
\hline Ölçümler & Gruplar & N & Ortalama & SS & P \\
\hline $\begin{array}{l}\text { Yumuşak damak kalınlık } \\
\text { SP1-SP2 (mm) }\end{array}$ & UDDY & 30 & 8,87 & 1,60 & \\
& Kontrol & 30 & 7,92 & 1,44 & 0.019 \\
\hline $\begin{array}{l}\text { Yumuşak damak } \\
\text { uzunluk PNS-P (mm) }\end{array}$ & UDDY & 30 & 30,18 & 3,80 & \\
\hline Kontrol & 30 & 33,66 & 3,01 & 0.000 \\
\hline $\begin{array}{l}\text { Yumuşak damak açıSı } \\
\text { ANS-PNS-P ( })\end{array}$ & UDDY & 30 & 126,96 & 6,80 & \\
\hline & Kontrol & 30 & 129,43 & 4,30 & 0.099 \\
\hline
\end{tabular}

N: örnek sayısI; SS: standart sapma

Grupların kranioservikal açılarının ortalamaları ve standart sapmaları Tablo 4'te görülmektedir. Kranioservikal postür açılarında (NSL/CVT ${ }^{\circ}$ ve NSL$\mathrm{OPT}^{\circ}$ ) iki grup arasında istatistiksel olarak anlamlı bir farklılık bulunmamıştır $(P>0,05)$.

\section{Tablo 4.}

Grupların kranioservikal postür açılarının ortalama, standart sapma ve karşılaştırmaları

\begin{tabular}{|lllccc} 
Ölçümler & Gruplar & N & Ortalama & SS & P \\
\hline \multirow{2}{*}{ NSL-OPT ( ${ }^{\circ}$ ) } & UDDY & 30 & 105,90 & 10,18 & \\
& Kontrol & 30 & 105,58 & 7,67 & 0.892 \\
\hline \multirow{2}{*}{ NSL-CVT ( ${ }^{\circ}$ ) } & UDDY & 30 & 104,26 & 20,70 & \\
& Kontrol & 30 & 108,48 & 7,96 & 0.302 \\
\hline
\end{tabular}

N: örnek sayısI; SS: standart sapma

\section{TARTIŞMA}

Nazofarenks ve orofarenks önemli konum ve fonksiyonlara sahiptirler; çünkü her ikisi de solunum ve yutmanın yapıldığı ünitenin bir parçasını oluşturur ve yapılarında lenfoid doku içerirler. ${ }^{18}$ Farengeal bölge, kemik bölmelerinin, kas fonksiyonlarının ve yumuşak dokuların kompleks etkileşimlerinden etkilenir. Bu bölge estetik yüz uyumunu da etkiler ve konuşmanın ve işitmenin anatomik temelini sağlar. ${ }^{19}$ Farenks ve dentofasiyal yapılar arasındaki yakın ilişki nedeniyle, farengeal yapılar ile dentofasiyal yapı arasında karşııkı 
bir etkileşimin oluşması beklenmektedir ve bu nedenle ortodontide her zaman ilgi konusu olmuştur. Dudak damak yarığına sahip hastaların farengeal yapısı konjenital deformite nedeniyle yarıksız bireylerden farklı olup üst havayolunun daha küçük olduğu bildirilmiştir. ${ }^{20}$ Çalışmamızda, UDDY sahip hastaların farengeal hava yolu alanı, yumuşak damak ölçümleri ve kraniyoservikal postürünün lateral sefalogramlar kullanılarak değerlendirilmesi ve bu değerlerin benzer yaş ve cinsiyetteki dudak damak yarığına sahip olmayan kontrol grubu hastaları ile karşılaştırılması planlanmıştır.

Çalışmamızda kullanılan lateral sefalometrik radyograflar üç boyutlu bir yapının iki boyutlu görünümünü tasvir ettiği için bu yöntemin doğruluğuyla ilgili tartışmalar mevcuttur. Havayolunun sefalometrik analizinde sagittal düzlemde anatomik olarak iyi tanımlanmış noktalarda hassas ölçümleri mümkün kıldığı için çalışmamızda lateral sefalogramlar kullanılmıştır. Riley ve ark., ${ }^{21}$ sefalogramlarla ölçülen farengeal havayolu alanı ile üç boyutlu bilgisayarlı tomografi taraması kullanılarak yapılan ölçümler arasında oldukça yüksek doğrulukta öngörülebilirlik ile yüksek derecede korelasyon $(r=0,92)$ bildirmişlerdir. Sefalometri ayrıca düşük maliyet, kolaylık, radyasyona az miktarda maruz kalma, baş konumunu, kraniyofasiyal morfolojiyi ve farengeal havayolunu aynı anda analiz edebilme özelliği de dahil olmak üzere diğer teknikler üzerinde önemli avantajlara sahiptir.

Çalışmamızda UDDY grubundaki hastaların kontrol grubuna kıyasla önemli ölçüde daha küçük toplam ve aerial nazofarengeal alana sahip olduğu bulunmuştur. Adenoidal alan ve orofarengeal alan gruplar arasında istatistiksel olarak anlamlı bir farklılık göstermemiştir. Benzer şekilde, Shahidi ve ark. $^{22}$ UDDY sahip hastaların farengeal havayolu hacimlerini normal bireylerle CBCT kullanarak karşılaştırdıkları çalışmalarında, total ve superior havayolu hacimlerinin UDDY grubundaki hastalarda anlamlı derecede daha düşük olduğunu ve inferior havayolu hacimlerinin iki grup arasında anlamlı farklılık göstermediğini bulmuşlardır. Imamura ve ark. $^{23}$ dudak damak yarıklı ve yarıksız erkek bireylerde adenoid dokuların ve üst solunum yollarının boyutlarını 2 boyutlu olarak karşılaştırdıkları çalışmalarında adölesan dönemde adenoid dokular arasında iki grup arasında anlamlı fark olmadığını ve üst solunum yolunun ise dudak damak yarığı grubunda önemli ölçüde küçük olduğunu bildirmişlerdir. Wada ve ark. ${ }^{24}$ UDDY sahip hastalarda nazofarengeal gelişimi, kontrol grubu ile karşılaștırdıkları çalıșmalarında, kraniyal taban bölgesi ve servikal vertebra gelişiminde kontrol grubuyla fark olmadığını; üst çene ve nazofarengeal gelişiminin kontrol grubuna göre daha az olduğunu bildirmişlerdir. Diwakar ve ark. ${ }^{25}$ UDDY sahip hastalarda farengeal hava yolu hacmini değerlendirdikleri çalışmalarında, nazofarengeal hava yolu hacminin kontrol grubuna göre anlamlı olarak küçük olduğunu bildirmişlerdir. Yoshihara ve ark. ${ }^{26}$ dudak damak yarıklı hastalar ve kontrol grubu arasında total orofarengeal hava yolu hacimleri açısından anlamlı bir fark olmadığını bildirmişlerdir. Bizim çalışmamızdan farklı olarak, Rana ve ark. ${ }^{27}$ yaptıkları çalışmalarında UDDY sahip çocuklarda toplam farengeal hacim, nazofarengeal, orofarengeal ve hipofarengeal alan ve hacim açısından yarıksız çocuklarla karşılaştırıldığında aralarında anlamlı bir fark olmadığını göstermişlerdir. Sonuçlardaki farklılığın nedenini çalışmalarında değerlendirdikleri UDDY sahip çocukların yarık defektlerinin farklı şiddette olması ve farklı merkezlerde, farklı protokollerle farklı sayıda opere edilmeleri şeklinde açıklamışlardır. Cheung ve Oberoi $^{28}$ çalışmalarında da bizim bulgularımızın aksine, nazofarengeal hava yolu hacminde dudak damak yarığı olan grupta havayolunun kısıtlanmadığını belirtmişlerdir. Dudak damak yarıklı çocuklarda daha geniş havayolu hacmi bulunmasını görüntülerin maksiller genişletme sonrası çekilmesi nedeniyle maksiller ekspansiyona bağlamışlardır. Çelikoğlu ve ark. ${ }^{29}$ yaptıkları çalışmalarında bizim çalışmamızdan farklı olarak, UDDY sahip hastalarda kontrol grubuna kıyasla orofarengeal havayolu hacmini anlamlı olarak daha küçük bulurken nazofarengeal havayolu hacminde iki grup arasında anlamlı bir farklılık olmadığını belirtmişlerdir.

Baş pozisyonu, kraniyofasiyal morfoloji ve farengeal havayolu arasındaki ilişki yumuşak doku germe hipotezi ile açıklanabilir. Bu hipoteze göre, havayolu yeterliliğindeki değişim kraniyoservikal açılarda değişimlerle sonuçlanan nöromüsküler geribildirimlere neden olmaktadır. ${ }^{30}$ Ansar ve ark. ${ }^{16}$ yaptıkları çalışmalarında mandibulanın vertikal büyüme paterni, kraniyoservikal postür ve farengeal havayolu alanı arasında ilişki bulunduğunu ve hiperdiverjan hastalarda normodiverjan ya da hipodiverjan hastalara kıyasla daha küçük nazofarengeal ve orofarengeal havayolu ve daha geniş kraniyoservikal açılar olduğunu rapor etmişlerdir. Bu bulgulara paralel olarak bizim çalışmamızda da, benzer vertikal büyüme modeli gösteren UDDY ve kontrol grupları arasında kraniyoservikal postür açıları arasında anlamlı bir fark bulunmamıştır. Azalmış farengeal havayollarının tipik olarak geniş bir kraniyoservikal açılanma ile bağlantılı olduğu belirtilmiştir. ${ }^{16}$ Baş genellikle küçük olan hava 
yolu alanını telafi etmek için ekstansiyona uğramaktadır. ${ }^{31}$ Aralarında istatistiksel olarak anlamlı bir fark bulunmamakla beraber, NSL/CVT ${ }^{\circ}$ açısının kontrol grubunda daha geniş bulunmasının kontrol grubunda orofarengeal alan değerlerinin daha küçük olmasıyla ilişkisi olabilir.

Tam yarıklı vakalarda, yarık insisiv foramen boyunca uzanır. Yumuşak damakta palatal kas liflerinin bağlanması ve oryantasyonu değişmiştir ve normalde orta hatta birleşen kaslar, sert damağın arka kenarına bağlanır. Bu nedenle, velofarengeal sfinkter fonksiyonu bozularak, velofarengeal yetmezliğe ve konuşma gelişiminde sorunlara yol açar. ${ }^{32}$ Yumuşak damağın uzunluğu ve fonksiyonu, nazofarenks derinliği ve genişliği ve posterior ve lateral faringeal duvarların hareketi gibi faktörler, konuşmanın kalitesini belirler. ${ }^{33}$ Çalışmamızda UDDY grubundaki hastaların yumuşak damaklarının daha kısa ve daha kalın olduğu bulunmuştur. Yumuşak damak onarımından dolayı bu beklenilen bir sonuçtur. Benzer şekilde, Wada ve ark. ${ }^{24}$ UDDY sahip hastalarda yumuşak damağın kontrol grubundaki hastalara göre daha kısa olduğunu bildirmişlerdir.

$\mathrm{Bu}$ çalışma ile UDDY hastalarının farengeal hava yolu alanları, yumuşak damak ölçümleri ve kraniyoservikal postür açıları lateral sefalogramlar kullanılarak değerlendirilmiş ve bu özellikler benzer yaş ve cinsiyetteki dudak damak yarığına sahip olmayan kontrol grubu hastaları ile karşılaştırılmıştır. Bulgularımız UDDY hastalarının aerial nazofarengeal alan ve total nazofarengeal alan değerlerinin anlamlı derecede kontrol grubundan düşük olduğunu ve UDDY grubundaki hastaların yumuşak damaklarının anlamlı derecede daha kalın ve daha kısa olduğunu göstermiştir. Çalışmamızın sıfır hipotezi reddedilmiştir. Literatür incelendiğinde UDDY hastalarının havayolunun değerlendirildiği çalışmalarda farklı sonuçların olduğu dikkat çekmektedir. Çalışmamızda cinsiyetler ve yaş grupları arasındaki farklııklar değerlendirilmemiştir. Sonuçların doğruluğunun değerlendirilebilmesi için örnek sayısının arttırılarak farklı yaştaki ve cinsiyetteki bireylerin de karşılaştırıldığı, ölçümlerin üç boyutlu olarak yapıldığı ilave çalışmalara intiyaç vardır.

\section{SONUÇ}

Sonuç olarak, UDDY sahip hastaların aerial ve toplam nazofarengeal alanları kontrol grubuna göre daha küçüktür. UDDY sahip hastalarda dar farengeal hava yolu fonksiyonel solunum bozukluğu ile sonuçlanabilir. UDDY sahip hastalarda farengeal yapı ve hava yolu fonksiyonu arasındaki ilişkiyi açıklayabilmek için daha ileri araştırmalar yapılmalı ve bu hastalarda ortodontik tedavi planlaması yapılırken, farengeal hava yolu üzerine pozitif bir etkiye sahip olmasına dikkat edilmelidir. 


\section{KAYNAKLAR}

1. Shapira Y, Lubit E, Kuftinec MM, Borell G. The distribution of clefts of the primary and secondary palates by sex, type, and location. Angle Orthod 1999; 69: 523-8.

2. Aylsworth AS. Genetic considerations in clefts of the lip and palate. Clin Plast Surg 1985; 12: 53342.

3. Lopatienè K, Dabkutè A, Juškevičiūtè V. Vertical and sagittal morphology of the facial skeleton and the pharyngeal airway. Stomatologija 2016; 18: 21-5.

4. Joseph AA, Elbaum J, Cisneros GJ, Eisig SB. A cephalometric comparative study of the soft tissue airway dimensions in persons with hyperdivergent and normodivergent facial patterns. J Oral Maxillofac Surg 1998; 56: 135-9.

5. Ozturk $Y$, Cura N. Examination of craniofacial morphology in children with unilateral cleft lip and palate. Cleft Palate Craniofac J 1996; 33: 32-6.

6. Silva Filho $O G$, Calvano $F$, Assunção $A G$, Cavassan AO. Craniofacial morphology in children with complete unilateral cleft lip and palate: a comparison of two surgical protocols. Angle Orthod 2001; 71: 274-84.

7. Warren DW, Duany LF, Fischer ND. Nasal pathway resistance in normal and cleft lip and palate subjects. Cleft Palate J 1969; 6: 134-40.

8. Hairfield WM, Warren DW, Seaton DL. Prevalence of mouthbreathing in cleft lip and palate. Cleft Palate J 1988; 25: 135-8.

9. Warren DW, Drake AF, Davis JU. Nasal airway in breathing and speech. Cleft Palate Craniofac J 1992; 29: 511-9.

10.Rose $E$, Staats R, Thissen U, Otten JE, Schmelzeisen R, Jonas I. Sleep-related obstructive disordered breathing in cleft palate patients after palatoplasty. Plast Reconstr Surg 2002; 110: 392-6.

11. MacLean JE, Hayward P, Fitzgerald DA, Waters $\mathrm{K}$. Cleft lip and/or palate and breathing during sleep. Sleep Med Rev 2009; 13: 345-54.

12. Marcus CL. Clinical and pathophysiological aspects of obstructive sleep apnea in children. Pediatr Pulmonol Suppl 1997; 16: 123-4.

13. Major MP, Flores-Mir C, Major PW. Assessment of lateral cephalometric diagnosis of adenoid hypertrophy and posterior upper airway obstruction: a systematic review. Am J Orthod Dentofacial Orthop 2006; 130: 700-8.
14.Aboudara C, Nielsen I, Huang JC, Maki K, Miller AJ, Hatcher D. Comparison of airway space with conventional lateral headfilms and 3-dimensional reconstruction from cone-beam computed tomography. Am J Orthod Dentofacial Orthop 2009; 135: 468-79.

15.Gohilot A, Pradhan T, Keluskar KM. Cephalometric evaluation of adenoids, upper airway, maxilla, velum length, need ratio for determining velopharyngeal incompetency in subjects with unilateral cleft lip and palate. J Indian Soc Pedod Prev Dent 2014; 32: 297-303.

16. Ansar J, Maheshwari S, Verma SK, Singh RK, Agarwal DK, Bhattacharya P. Soft tissue airway dimensions and craniocervical posture in subjects with different growth patterns. Angle Orthod 2015; 85: 604-10.

17. Houston WJ. The analysis of errors in orthodontic measurements. Am J Orthod 1983; 83: 382-90.

18. Agarwal V, Reddy G, Jain S, Goyal V, Chugh T. Relation of pharynx with orofacial structures in Jaipur (India) population exhibiting normal occlusion with respect to sex: a cross sectional study. J IndOrthodSoc 2011; 45: 207-11.

19. Wermker K, Jung $S$, Joos $U$, Kleinheinz J. Nasopharyngeal development in patients with cleft lip and palate: a retrospective case-control study. Int J Otolaryngol 2012; 2012: 458-507.

20.Warren DW. A quantitative technique for assessing nasal airway impairment. Am $\mathrm{J}$ Orthod 1984; 86; 306-14.

21.Riley RW, Powell NB, Guilleminault C. Cephalometric roentgenograms and computerized tomographic scans in obstructive sleep apnea. Sleep 1986; 9: 514-5.

22. Shahidi S, Momeni Danaie S, Omidi M. Comparison of the Pharyngeal Airway Volume between Non-Syndromic Unilateral Cleft Palate and Normal Individuals Using Cone Beam Computed Tomography. J Dent (Shiraz) 2016; 17: 268-75.

23. Imamura N, Ono T, Hiyama S, Ishiwata $\mathrm{Y}$, Kuroda T. Comparison of the sizes of adenoidal tissues and upper airways of subjects with and without cleft lip and palate. Am J Orthod Dentofacial Orthop 2002; 122: 189-94.

24. Wada T, Satoh K, Tachimura T, Tatsuta U. Comparison of nasopharyngeal growth between patients with clefts and noncleft controls. Cleft Palate Craniofac J 1997; 34: 405-9. 
25.Diwakar R, Sidhu MS, Jain S, Grover S, Prabhakar M. Three-dimensional evaluation of pharyngeal airway in complete unilateral cleft individuals and normally growing individuals using cone beam computed tomography. Cleft Palate Craniofac J 2015; 52: 346-51.

26. Yoshihara M, Terajima M, Yanagita N, Hyakutake $H$, Kanomi R, Kitahara T, et al. Three-dimensional analysis of the pharyngeal airway morphology in growing Japanese girls with and without cleft lip and palate. Am J Orthod Dentofacial Orthop 2012; 141: 92-101.

27.Rana SS, Duggal R, Kharbanda OP. Area and volume of the pharyngeal airway in surgically treated unilateral cleft lip and palate patient: A cone beam computed tomography study. Journal of Cleft Lip and Palate and Craniofacial Anomalies 2015; 2: 27-33.

28. Cheung T, Oberoi S. Three dimensional assessment of the pharyngeal airway in individuals with nonsyndromic cleft lip and palate. PLoS One 2012; 7 : e43405.

29. Celikoglu M, Buyuk SK, Sekerci AE, Ucar FI, Cantekin K. Three-dimensional evaluation of the pharyngeal airway volumes in patients affected by unilateral cleft lip and palate. Am $\mathrm{J}$ Orthod Dentofacial Orthop 2014; 145: 780-6.

30.Solow B, Kreiborg S. Soft-tissue stretching: a possible control factor in craniofacial morphogenesis. Scand J Dent Res 1977; 85: 505-7.

31. Hellsing $\mathrm{E}$. Changes in the pharyngeal airway in relation to extension of the head. Eur $\mathrm{J}$ Orthod 1989; 11: 359-65.

32.van Aalst JA, Kolappa KK, Sadove M. MOC-PSSM CME article: Nonsyndromic cleft palate. Plast Reconstr Surg 2008; 121: 1-14.

33. McWilliams BJ, Musgrave RH. Diagnosis of speech problems in patients with cleft palate. $\mathrm{Br} \mathrm{J}$ Disord Commun 1971; 6: 26-32.

Yazışma Adresi:

Yrd.Doç.Dr. Zeliha Müge BAKA

Selçuk Üniversitesi

Diş Hekimliği Fakültesi Ortodonti AD

Selçuklu, Konya

Tel : +90 3322231172

Faks : +90 3322230062

E-mail: mugen97@hotmail.com 